\title{
СТРАТЕГІЧНИЙ ПІДХІД ДО ВИЗНАЧЕННЯ ПРІОРИТЕТНИХ НАПРЯМІВ РОЗВИТКУ БРЕНДІВ ОБ'ЄДНАНИХ ТЕРИТОРІАЛЬНИХ ГРОМАД
}

\author{
Колодненко Наталія Володимирівна \\ Сумський національний аграрний університет (м. Суми, Україна) \\ ORCID: 0000-0002-8661-9511 \\ kolodnenko78n@ukr.net
}

Запропоновано стратегічний підхід до визначення пріоритетних напрямів розвитку брендів об'єднаних територіальних громад, який базується на виокремленні суббрендів ОТГ типу соціально-підприємницького пріоритету, еколого-туристичного пріоритету, соціально-екологічного пріоритету та підприємницько-туристичного пріоритету.

Ключові слова: бренд, об'єднана територіальна громада, суббренд, стратегія розвитку.

DOI: https://doi.org/10.32845/bsnau.2019.4.19

Вступ. Однією з передумов створення ефективної стратегії бренду об'єднаних територіальних громад є визначення пріоритетних напрямів маркетингової політики географічних одиниць, спрямованої на формування особливих (притаманних саме певній територіальній громаді) конкурентних переваг, які відображатимуть цінності, властивості, відмінну ідентичність та головну ідею розвитку та функціонування ОТГ.

Аналіз останніх досліджень і публікацій. Науковці, які займаються вивченням проблеми розвитку територіальних громад та брендингу територій $[2,3,4,5,6,7]$ сходяться у думці, що громади та території, яким притаманне поступове впровадження взаємопов'язаних маркетингових заходів, $є$ більш конкурентоспроможними та успішними в своєму розви-

тку. Пріоритетним для таких територіальних одиниць є досягнення цілей сталого розвитку шляхом залучення інвестицій, розвитку малого та середнього підприємництва, створення привабливого іміджу, налагодження стратегічних партнерських відносин, посилення туристичної привабливості та поліпшення добробуту населення.

Виклад основного матеріалу. За результатами проведених польових досліджень ми зробили висновок щодо існування залежності бюджетної ефективності ОТГ від наявності стратегії розвитку. Як видно з таблиці 1., ОТГ з найменшою бюджетною ефективністю не мають стратегій розвитку, а всі ОТГ з найбільшою бюджетною ефективністю функціонують за розробленою стратегією.

Таблиця 1

Аналіз залежності бюджетної ефективності ОТГ від наявності стратегії розвитку як фактору впливу на успішність функціонування громади

\begin{tabular}{|c|c|c|c|c|}
\hline Назва ОТГ & $\begin{array}{c}\text { Доходи загального фонду на 1-го мешканця, } \\
\text { грн. (фінансовий потенціал ОТГ) }\end{array}$ & $\begin{array}{c}\text { Видатки загального фонду на } \\
\text { 1- го мешканця, грн. }\end{array}$ & $\begin{array}{c}\text { Бюджетна } \\
\text { ефективність ОТГ }\end{array}$ & $\begin{array}{c}\text { Наявність стратегії } \\
\text { розвитку }\end{array}$ \\
\hline Чернеччинська & 9637 & 10338,6 & 0,93 & + \\
\hline Дружбівська & 5706,3 & 6162,2 & 0,93 & + \\
\hline Шалигинська & 6032,7 & 6532,3 & 0,92 & + \\
\hline Комишанська & 12599,6 & 13869,3 & 0,91 & + \\
\hline Степанівська & 5649,8 & 6252,7 & 0,90 & + \\
\hline Дубов'язівська & 6261,6 & 7054,9 & 0,89 & + \\
\hline Березівська & 6770,7 & 7760,6 & 0,87 & + \\
\hline Миколаївська & 6009,4 & 6911,2 & 0,87 & + \\
\hline Андріяшівська & 6021,6 & 7094,8 & 0,85 & + \\
\hline Бочечківська & 6789,1 & 8213 & 0,83 & + \\
\hline Вільшанська & 4943,2 & 6226,7 & 0,79 & - \\
\hline Краснопільська & 5180,6 & 6606 & 0,78 & + \\
\hline Хотінська & 5301,2 & 6911,5 & 0,77 & + \\
\hline Боромлянська & 5550,7 & 7249,7 & 0,77 & + \\
\hline Кролевецька & 3981,5 & 5295,6 & 0,75 & - \\
\hline Недригайлівська & 5030,5 & 6713,1 & 0,75 & + \\
\hline Новослобідська & 5416,9 & 7327,6 & 0,74 & - \\
\hline Коровинська & 3582,8 & 4886,7 & 0,73 & + \\
\hline Тростянецька & 5219,6 & 7323,6 & 0,71 & + \\
\hline Миколаївська (Білопільський район) & 5036,6 & 7243,1 & 0,70 & + \\
\hline Буринська & 4669 & 6723,7 & 0,69 & - \\
\hline Білопільська & 4961,5 & 7213,1 & 0,69 & + \\
\hline Зноб-Новгородська & 5093,5 & 8191,5 & 0,62 & + \\
\hline Миропільська & 4560,7 & 7734,7 & 0,59 & + \\
\hline Кириківська & 3158,1 & 5667,9 & 0,56 & + \\
\hline Нижньосироватська & 3028,2 & 5611,2 & 0,54 & - \\
\hline Верхньосироватська & 3032,2 & 6108,3 & 0,50 & - \\
\hline Чупахівська & 2346,2 & 4961,7 & 0,47 & - \\
\hline Грунська & 2539,3 & 5822 & 0,44 & - \\
\hline Шосткинська & 3266,9 & 7548,7 & 0,43 & - \\
\hline
\end{tabular}


Отже, гіпотезу щодо існування закономірності між успішністю функціонування об'єднаної територіальної громади та стратегічним підходом в управлінні було підтверджено, що своєю чергою, формує передумову для доцільності розробки стратегічного підходу до визначення пріоритетних напрямів розвитку брендів об'єднаних територіальних громад.

Враховуючи те, що до основних груп цільової аудиторії в територіальному брендингу науковці $[1,2,6]$ відносять інвесторів, підприємців, партнерів, місцеве населення та туристів а також керуючись головними напрямами стратегії сталого економічного розвитку України (інвестиційна привабливість, розвиток підприємництва, енергоефективність, захист навколишнього середовища, соціальна орієнтованість) пропонуємо в якості пріоритетних напрямів розвитку брендів об'єднаних територіальних громад розглядати наступні:

- бренди групи соціального пріоритету ОТГ;

- бренди групи підприємницького пріоритету ОТГ;

- бренди групи туристичного пріоритету ОТГ;

- бренди групи екологічного пріоритету ОТГ.

Крім того, процес брендингу об'єднаних територіаль- них громад передбачає по-перше, позиціонування, яке реалізується через визначення найсильніших та виняткових конкурентних переваг території з метою формування унікальної позиції; по-друге - просування, що передбачає максимальну відповідність запитам цільової аудиторії, враховуючи наявні та потенційні ресурси. Головною метою брендингу ОТГ має стати максимальна концентрація на перевагах території та чітке відображення наявних конкурентних переваг. Завданням бренду ОТГ є створення з усіма групами цільової аудиторії певних відносини, формування емоційної прив'язаності і лояльності.

Отже, беручи до уваги запропоноване нами розподілення брендів ОТГ за пріоритетними напрямами розвитку, архітектоніку бренду Сумського регіону пропонуємо розглядати як зонтичний бренд, який поєднує в собі суббренди об'єднаних територіальних громад, розподілених за критерієм пріоритетності розвитку на чотири групи: суббренди групи соціального пріоритету ОТГ, суббренди групи підприємницького пріоритету ОТГ, суббренди групи туристичного пріоритету ОТГ, суббренди групи екологічного пріоритету OTГ (рис.1).

Зонтичний бренд Сумського регіону

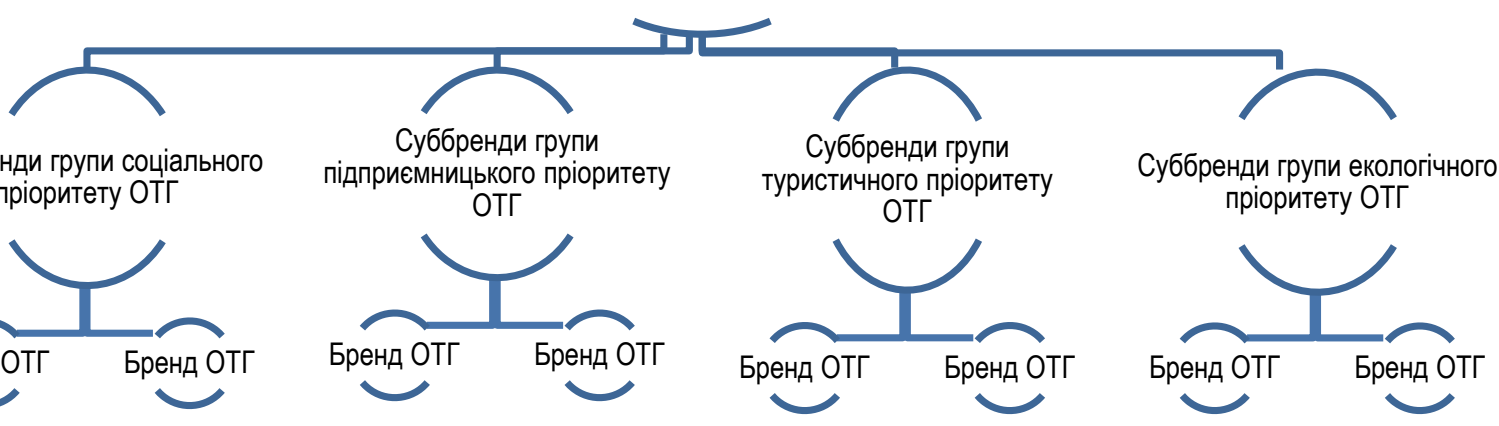

Puc. 1. Архітектоніка бренду Сумського регіону

Запропонована архітектонічна структура передбачає розробку економічно обірунтованого інструментарію щодо визначення пріоритетних напрямів розвитку брендів об'єднаних територіальних громад, використання якого дозволить розподілити об'єднані територіальні громади на відповідні групи та запропонувати стратегії розвитку брендів ОТГ виходячи з встановленої пріоритетності. 3 цією метою, автором дисертаційної роботи пропонується використовувати методи багатомірного аналізу: факторний аналіз - з метою відбору інформативних ознак поділу ОТГ; кластерний аналіз - з метою розподілення на групи суббрендів; метод інтегрального оцінювання - з метою визначення альтернативних шляхів у стратегічному розвитку суббрендів ОТГ. Визначення пріоритетних напрямів розвитку брендів об'єднаних територіальних громад пропонується проводити на основі наступної послідовності етапів, яку представлено на рис. 2.

Відповідно запропонованій послідовності, на першому етапі визначення пріоритетних напрямів розвитку брендів об'єднаних територіальних громад необхідно провести діагностику конкурентного середовища, внутрішніх та зовнішніх факторів впливу з метою виявлення конкурентних переваг певної ОТГ. 3 цією метою було досліджено стратегії розвитку 11 ОТГ Сумського регіону на предмет виокремлення головних конкурентних переваг ґрунтуючись на заявленій місії та проведеному SWOT-аналізі.

На другому етапі необхідно сформувати систему показників, які комплексно характеризуватимуть пріоритетність напрямів розвитку брендів об'єднаних територіальних громад на основі наступних складових: брендинг соціального пріоритету (Б_сп), брендинг підприємницького пріритету (Б_пп), брендинг туристичного пріоритету (Б_тп), брендинг екологічного пріоритету (Б_еп). На нашу думку, такими показниками є:

- чисельність населення, тис.ос;

- питома вага заробітної плати у видатках загального фонду (\%);

- кількість закладів загальної середньої освіти на одну дитину;

- кількість дошкільних навчальних закладів на одну дитину;

- кількість закладів охорони здоров'я на одного мешканця;

- кількість закладів культурно-просвітницької діяльності на одного мешканця;

- доходи загального фонду на одного мешканця, грн.;

- капітальні видатки на 1-го мешканця (грн.)

- кількість суб'єктів підприємництва на одного мешканця;

- наявність програми розвитку малого та середнього бізнесу;

- кількість закладів готельно-ресторанного господарства 
на одного мешканця;

- кількість рекреаційних об'єктів;
- рейтинг інституційної спроможності та сталого розвитку; - питома вага викидів $\mathrm{CO}_{2}$.

Етап 1 Діагностика конкурентного середовища, внутрішніх та зовнішніх фракторів впливу з метою виявлення конкурентних переваг певної ОТГ

Етап 2 Формування системи показників для визначення пріоритетних напрямів розвитку брендів об'єднаних територіальних громад на основі складових: брендинг соціального пріоритету $\left(\mathrm{B}_{\text {сп }}\right)$, брендинг підприємницького пріритету $\left(\mathrm{b}_{\text {пп }}\right)$, брендинг туристичного пріоритету $\left(\mathrm{b}_{\text {тп }}\right)$, брендинг екологічного пріоритету $\left(\mathrm{Б}_{\mathrm{en}}\right)$

Етап 3 Проведення факторного аналізу системи показників з метою відбору інформативних ознак поділу ОТГ за складовими (Бсп), (Бпп), (Бтп), (Беп) та визначення факторних навантажень (коефріцієнтів вагомості) для розрахунку інтегрального показника розвитку зонтичного бренду Сумського регіону

$X_{i k}=a_{1 k} f_{i 1}+K+a_{t k} f_{i t}+e_{i k}$

де $X_{i k}$ - значення k -ої ознаки для і -го об'єкта у вигляді лінійних комбінацій значень $f_{i t}$ факторів $f_{t}$ на об'єктах з нев'язками $e_{i k}$

Етап 4 Включення ј-го часткового показника і-ої складової до групи найбільш впливових з метою подальшої кластерізації об’єктів (ОТГ) на основі обраних показників

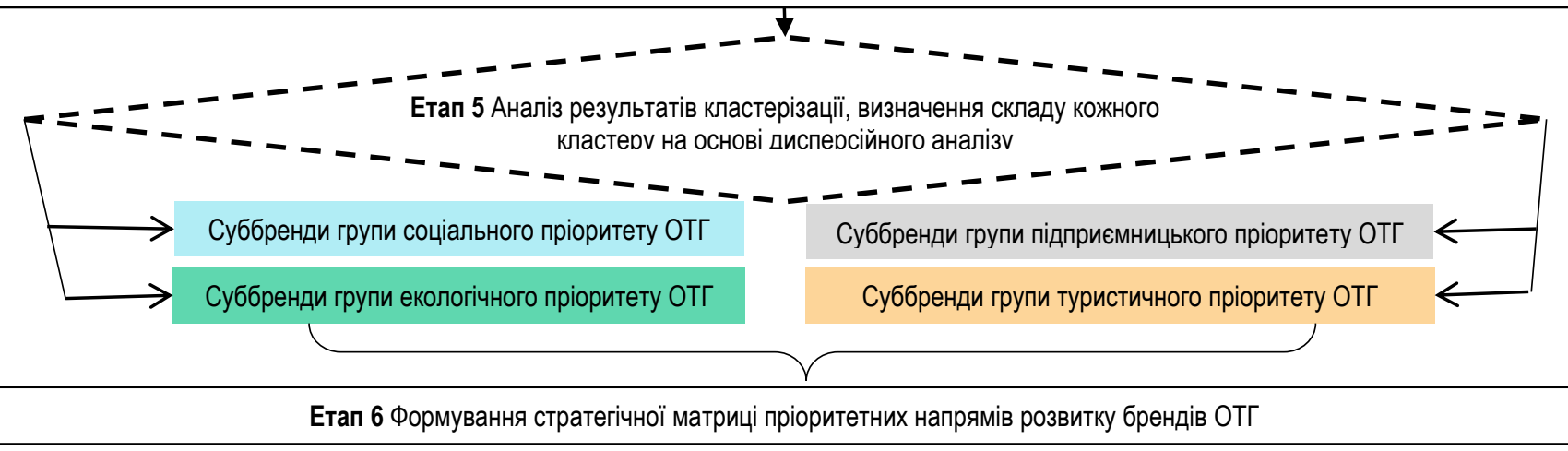

Puc. 2 Послідовність етапів визначення пріоритетних напрямів розвитку брендів об'єднаних територіальних громад

Висновки. Запропоновано стратегічний підхід до визначення пріоритетних напрямів розвитку брендів об'єднаних територіальних громад, який базується на виокремленні суббрнедів ОТГ типу соціально-підприємницького пріоритету, еколого-туристичного пріоритету, соціально-екологічного

пріоритету та підприємницько-туристичного пріоритету. Це дозволить побудувати уніфікований алгоритм розроблення, розвитку та впровадження територіального брендингу з врахуванням унікальних конкурентних переваг окремих ОТГ.

\section{Список використаної літератури:}

1. Anholt, S. Competitive Identity: The New Brand Management for Nations, Cities and Regions / S. Anholt. - 1st edition. Palgrave Macmillan, 2007. - $160 \mathrm{p}$.

2. Велещук С.С. Територіальний брендинг як інструмент соціально-економічного розвитку регіону / С.С. Велещук // Сталий розвиток економіки . - 2015. - №3(28). - С. 146-152.

3. Павлова І.О. Стратегія брендингу об'єднаних територіальних громад Південного регіону / І.О. Павлова// Вісник ОНУ імені І.І. Мечникова. - 2017. - Т22. - Вип. 12(65). - С. 199-203.

4. Ресурсне забезпечення об'єднаної територіальної громади та її маркетинг: навч. посіб. /[Г. А. Борщ, В. М. Вакуленко, Н. М. Гринчук, Ю. Ф. Дехтяренко, О. С. Ігнатенко,В. С. Куйбіда, А. Ф. Ткачук, В. В. Юзефович] - К. : - 2017. - 107 с.

5. Бутенко А. І. Інноваційні підходи до оцінки економічної самодостатності територіальних громад / А. І. Бутенко, Т. В. Уманець, О. В. Дарієнко // Економічні інновації. - 2016. - № 62. - С. 223-231.

6. Управління стратегічним розвитком об'єднаних територіальних громад: інноваційні підходи та інструменти : монографрія / С. М. Серьогін, Ю. П. Шаров, Є. І. Бородін, Н. Т. Гончарук [та ін.] ; за заг. та наук. ред. С. М. Серьогіна, Ю. П. Шарова. - Д. : ДРІДУ НАДУ, 2016. - 276 с.

Natalia Kolodnenko, Sumy National Agrarian University (Sumy, Ukraine)

Strategic approach to determining the priority areas of brand development of united territorial communities

It is proposed the strategic approach to determining the priority areas of brand development of united territorial communities (UTC), which is based on the separation of UTC subbrands such as social-entrepreneurial priority, ecological-tourist priority, socioecological priority and entrepreneurial-tourist priority.

Keywords: brand, united territorial community, subbrand, development strategy

Дата надходження до редакції: 20.10.2019 р. 